\title{
PEMANFAATAN SUHU UDARA DAN KELEMBAPAN UDARA DALAM PERSAMAAN REGRESI UNTUK SIMULASI PREDIKSI TOTAL HUJAN BULANAN DI PANGKALPINANG
}

\author{
Akhmad Fadholi \\ Stasiun Meteorologi Depati Amir Pangkalpinang \\ email: akhmad.fadholi@bmkg.go.id
}

\begin{abstract}
ABSTRAK
Simulasi prediksi curah hujan bulanan (RR) dengan menggunakan prediktor suhu udara (T) dan kelembapan udara (RH) telah dicoba dilakukan di Stasiun Meteorologi Depati Amir Pangkalpinang. Evaluasi dilakukan dengan membandingkan dan menghitung besarnya penyimpangan prediksi total hujan bulanan terhadap total hujan aktualnya. Simulasi prediksi total hujan bulanan ini digunakan dua metode regresi, yaitu regresi linier sederhana dan regresi linier berganda. Hasil pengolahan data menunjukkan bahwa simulasi prediksi total hujan bulanan tahun 2011 di daerah studi didapatkan rerata RMSE $=14.8 \mathrm{~mm} / \mathrm{bulan}$ menggunakan prediktor suhu udara, RMSE $=14.5 \mathrm{~mm} /$ bulan menggunakan prediktor kelembapan udara, dan RMSE $=14.9 \mathrm{~mm} /$ bulan menggunakan prediktor suhu udara dan kelembapan udara sekaligus.
\end{abstract}

Kata Kunci: Hujan Bulanan, Kelembaban Udara, Linear, Regresi, Suhu Udara

\section{ABSTRACT}

Monthly rainfall prediction simulation (RR) using air temperature $(T)$ and relative humidity $(R H)$ as predictors, has been done at Meteorological Station Depati Amir Pangkalpinang. Evaluation of prediction was examined by comparing and computing between the prediction output and observation values. Both linear and multi-linear regression methods were used in data processing. Results show the monthly rainfall prediction simulation of 2011 having the mean of RMSE $=14.8 \mathrm{~mm} /$ month using air temperature data as predictor, $R M S E$ $=14.5 \mathrm{~mm} /$ month using relative humidity data as predictor, and $R M S E=14.9 \mathrm{~mm} / \mathrm{month}$ using both air temperature and relative humidity data as predictors at onces.

Key words: Monthly Rainfall, Relative Humidity, Linear, Regression, Air Temperature

\section{PENDAHULUAN}

Kota Pangkalpinang berada di wilayah Belahan Bumi selatan. Secara geografis (Sandy, 1995) kota Pangkalpinang terletak pada $02^{\circ} 04^{\prime}$ $02^{\circ} 10^{\prime} \mathrm{LS}$ dan $106^{\circ} 04^{\prime}-106^{\circ} 07^{\prime}$ BT dengan lingkungan fisik sekitar stasiun pada umumnya adalah perumahan, hutan, dan pantai. Di wilayah tropis, curah hujan merupakan salah satu unsur iklim yang paling tinggi keragamannya (Wirjohamidjojo dan Swarinoto, 2010). Karakteristik curah hujan di berbagai daerah tentunya tidak sama. Kondisi ini diakibatkan oleh beberapa faktor (Nieuwolt, 1977), yakni: geografis, topografis, dan orografis. Belum lagi ditambah dengan struktur dan orientasi kepulauan (Kartasapoetra, 2006). Akibatnya pola sebaran curah hujan cenderung tidak merata antara daerah yang satu dengan daerah yang lain dalam ruang lingkup yang luas. Mengingat bahwa hujan di wilayah ropis banyak berpengaruh terhadap kehidupan manusia dalam segala aspeknya (Wirjohamidjojo dan Swarinoto, 2007), maka penulis berusaha mengumpulkan dan melakukan pengolahan data curah hujan dimaksud. Selain itu disertai juga dengan pengolahan data suhu udara dan kelembapan udara selama 21 tahun di Stasiun Meteorologi Depati Amir Pangkalpinang. Sementara itu untuk pembuatan simulasi prediksi total hujan bulanan digunakan metode regresi linier sederhana dan regresi linier berganda. Bertalian dengan adanya tipe-tipe total hujan bulanan, maka presisi prediksi total hujan bulanan akan berbeda-beda dari tempat yang satu dengan tempat yang lain. Prediksi total hujan bulanan dengan metode tertentu sangat sesuai dengan tempat yang satu, tetapi dapat juga tidak sesuai pada tempat yang lain. Untuk itu evaluasi prediksi total hujan bulanan sangat diperlukan sehingga hasil kajian dapat digunakan sebagai masukan dalam menyiapkan prediksi total hujan bulanan pada bulan-bulan berikutnya.

\section{A. Curah Hujan}

Curah hujan adalah butir-butir air atau kristal es yang jatuh atau keluar dari awan atau 
kelompok awan. Jika curahan dimaksud dapat mencapai permukaan bumi disebut sebagai hujan (Tjasyono, 1999). Jika setelah keluar dari dasar awan tetapi tidak jatuh sampai ke permukaan bumi disebut sebagai virga (Soepangkat, 1994). Butir air yang dapat keluar dari awan dan mampu mencapai permukaan bumi harus memiliki garis tengah paling tidak sebesar 200 mikrometer (1 mikrometer $=0,001 \mathrm{~cm}$ ). Kurang dari ukuran diameter tersebut, butir-butir air dimaksud akan habis menguap di atmosfer sebelum mampu mencapai permukaan bumi5). Banyaknya curah hujan yang mencapai permukaan bumi atau tanah selama selang waktu tertentu dapat diukur dengan jalan mengukur tinggi air hujan dengan cara tertentu. Hasil dari pengukurannya dinamakan curah hujan, yaitu tanpa mengingat macam atau bentuknya pada saat mencapai permukaan bumi dan tidak memperhitungkan endapan yang meresap ke dalam tanah, hilang karena penguapan, atau pun mengalir.

Dari bentuk dan sifatnya, hujan ada yang disebut dengan shower atau hujan tiba-tiba. Hujan tersebut ditandai dengan permulaan dan akhir yang mendadak dengan variasi intensitas yang umumnya cepat, dengan titik-titik air atau partikelpartikel yang lebih besar daripada hujan biasa dan jatuhnya dari awan-awan Cumulus ( $\mathrm{Cu}$ ) ataupun Cumulonimbus ( $\mathrm{Cb}$ ) yang pertumbuhannya bersifat konvektif. Hujan kontinu yang permulaan dan akhirnya tidak secara mendadak dan tidak tampak terjadi pengurangan perawanan sejak permulaan sampai pada akhirnya aktifitas tersebut. Hujan ini jatuhnya dari awan-awan yang pada umumnya berbentuk merata seperti awanawan Stratus (St), Altostratus (As), maupun Nimbustratus (Ns).

\section{B. Suhu Udara}

Untuk keperluan operasional Klimatologi di Indonesia, khususnya bagi stasiun yang beroperasi kurang dari 24 jam sehari, maka suhu udara permukaan rata-rata harian dapat dihitung dengan persamaan berikut:

$$
T_{\text {mean }}=\frac{2^{*} T_{7}+T_{13}+T_{18}}{4}
$$

Dengan:

Tmean = suhu udara permukaan ratarata harian $\left({ }^{\circ}\right)$,

$\mathrm{T}_{7}=$ suhu udara pengamatan jam 07.00 LT;

$\mathrm{T}_{13}=$ suhu udara pengamatan jam $13.00 \mathrm{LT}$;

$\mathrm{T}_{18}=$ suhu udara pengamatan jam8.00 LT.

Keadaan suhu udara pada suatu tempat di permukaan bumi akan ditentukan oleh faktorfaktor (Tanudidjaja, 1993) sebagai berikut :

\section{a) Lamanya Penyinaran Matahari}

Semakin lama matahari memancarkan sinarnya disuatu daerah, makin banyak panas yang diterima. Keadaan atmosfer yang cerah sepanjang hari akan lebih panas daripada jika hari itu berawan sejak pagi.

b) Kemiringan Sinar Matahari

Suatu tempat yang posisi matahari berada tegak lurus di atasnya, maka radiasi matahari yang diberikan akan lebih besar dan suhu ditempat tersebut akan tinggi, dibandingkan dengan tempat yang posisi mataharinya lebih miring.

c) Keadaan Awan

Adaya awan di atmosfer akan menyebabkan berkurangnya radiasi matahari yang diterima di permukaan bumi. Karena radiasi yang mengenai awan, oleh uap air yang ada di dalam awan akan dipencarkan, dipantulkan, dan diserap.

\section{d) Keadaan Permukaan Bumi}

Perbedaan sifat darat dan laut akan mempengaruhi penyerapan dan pemantulan radiasi matahari. Permukaan darat akan lebih cepat menerima dan melepaskan panas energy radiasi matahari yang diterima dipermukaan bumi dan akibatnya menyebabkan perbedaan suhu udara di atasnya.

\section{Kelembapan Udara}

Kelembapan udara adalah banyaknya uap air yang terkandung dalam udara atau atmosfer. Besarnya tergantung dari masuknya uap air ke dalam atmosfer karena adanya penguapan dari air yang ada di lautan, danau, dan sungai, maupun dari air tanah. Disamping itu terjadi pula dari proses transpirasi, yaitu penguapan dari tumbuhtumbuhan. Sedangkan banyaknya air di dalam udara bergantung kepada banyak faktor, antara lain adalah ketersediaan air, sumber uap, suhu udara, tekanan udara, dan angin ${ }^{5}$. Uap air dalam atmosfer dapat berubah bentuk menjadi cair atau padat yang akhirnya dapat jatuh ke bumi antara lain sebagai hujan. Kelembapan udara yang cukup besar memberi petunjuk langsung bahwa udara banyak mengandung uap air atau udara dalam keadaan basah. Berbagai ukuran dapat digunakan untuk menyatakan nilai kelembapan udara. Salah satunya adalah kelembapan udara relative (nisbi). Kelembapan udara nisbi (Wirjohamidjojo, 2006) memiliki pengertian sebagai nilai perbandingan antara tekanan uap air yang ada pada saat pengukuran (e) dengan nilai tekanan uap air maksimum $\left(\mathrm{e}_{\mathrm{m}}\right)$ yang dapat dicapai pada suhu udara dan tekanan udara saat 
pengukuran. Persamaan untuk kelembapan udara relatif adalah seperti berikut:

$$
R H=\frac{e}{e_{m}} \times 100
$$

Dengan:

$$
\begin{aligned}
R H= & \text { kelembapan udara relatif }(\%), \\
e= & \text { tekanan uap air pada saat } \\
& \text { pengukuran (mb), } \\
e_{m}= & \text { tekanan uap air maksimum yang } \\
& \text { dapat dicapai pada suhu udara dan } \\
& \text { tekanan udara saat pengukuran } \\
& (\mathrm{mb}) .
\end{aligned}
$$

\section{METODE PENELITIAN}

\section{A. Data}

Data yang digunakan dalam tulisan ini adalah data iklim yang diperoleh dari Stasiun Meteorologi Depati Amir Pangkalpinang, yang terdiri atas:

(1). Data total curah hujan bulanan

(2). Data rerata suhu udara bulanan

(3). Data rerata kelembapan udara bulanan

Data suhu udara dan kelembapan udara bulanan merupakan rata-rata bulanan hasil dari jumlah data rata-rata harian selama satu bulan kemudian dibagi dengan banyaknya data pada bulan yang bersangkutan. Panjang data yang digunakan adalah 22 tahun dari tahun 1990 2011. Data total hujan, suhu udara, dan kelembapan udara bulanan selama 21 tahun (1990-2010), digunakan untuk membentuk persamaan regresi. Data suhu udara dan kelembapan udara bulanan tahun 2011 digunakan untuk memprediksi total hujan. Sedangkan data total hujan bulanan pada tahun 2011 digunakan sebagai pembanding dalam melakukan verifikasi hasil prediksi total hujan bulanan.

\section{B. Metode}

\section{a) Regresi Linier Sederhana}

Metode prediksi regresi linier sederhana dilakukan dengan cara membentuk persamaan regresi agar dapat melakukan simulasi memprediksi total hujan bulanan di Stasiun Meteorologi Depati Amir Pangkalpinang. Adapun persamaan yang digunakan (Nazir, 2003) adalah sebagai berikut:

$$
Y=A+B X
$$

Dengan:

$\mathrm{Y}=$ variabel yang diduga predictant/dependent), A = konstanta,

$\mathrm{B}=$ koefisien regresi, dan $\mathrm{X}=$ variabel penduga (predictor /independent).
Koefisien A dan B pada persamaan di atas dapat dihitung dengan cara sebagai berikut:

Sedangkan:

$$
B=\frac{n \sum X Y-\left(\sum X\right)\left(\sum Y\right)}{n \sum X^{2}-\left(\sum X\right)^{2}}
$$

$$
A=\text { Ymean }-B * \text { Xmean }
$$

Dengan:

$\mathrm{X}=$ data suhu udara (kelembapan udara); $\mathrm{Y}=$ data total hujan $(\mathrm{mm})$; dan $\mathrm{n}=$ banyak data .

\section{b) Regresi Linier Berganda}

Metode prediksi regresi linier berganda ini dilakukan dengan cara membentuk persamaan regresi yang digunakan untuk melakukan simulasi prediksi total hujan bulanan menggunakan lebih dari dari satu variable independen. Hasil prediksi total hujan bulanan menggunakan metode ini dibandingkan dengan prediksi total hujan bulanan menggunakan regresi linier sederhana sehingga dapat terlihat hasil prediksi yang lebih baik setelah dicocokkan dengan data observasi. Adapun persamaan umum (Usman dan Akbar, 2000) metode ini adalah sebagai berikut:

$$
\begin{aligned}
Y & =B_{0}+B_{1} X_{1}+B_{2} X_{2} \\
& +\ldots .+B_{k} X_{k}
\end{aligned}
$$

Dengan: Bo = konstanta; B1, B2, ..... Bk = koefisien variabel $\mathrm{X}_{1}, \mathrm{X}_{2}, \ldots . . \mathrm{X}_{\mathrm{k}} ; \mathrm{Y}=$ variable yang diduga (variabel dependent); dan $X_{i}=$ variabel penduga (variabel independent).

Untuk analisis dengan metode regresi dibedakan dua jenis variabel ialah variable bebas (independent) atau variabel prediktor dan variabel tidak bebas (dependent) atau variable respon. Variabel bebas merupakan variable yang dapat mempengaruhi varibel tidak bebas atau variabel yang dapat memprediksi harga variabel tidak bebas. Variabel ini dinyatakan dengan $\mathrm{X}_{1}, \mathrm{X}_{2}$, ..., $\mathrm{X}_{\mathrm{k}}$. Sedangkan variabel tidak bebas merupakan variabel yang terjadi karena variabel bebas atau variabel yang mencerminkan respon dari variabel bebas, dinyatakan dengan Y (Sudjana, 1995). Dalam tulisan ini variabel bebas (independent) atau prediktor adalah suhu udara dan kelembapan udara, sedangkan variabel tidak bebas (dependent) atau variabel respon adalah total hujan. Proses pembuatan prakiraan ada dua tahap, tahap pertama membuat persamaan regresi untuk tiap bulan berdasarkan bulan yang sama selama 21 tahun dari tahun 1990 - 2010 dan tahap kedua memprediksi total hujan bulan dengan memberikan nilai variabel penduga (prediktor) pada persamaan regresi yang dibuat. Dalam penginputan data prediktor pada masingmasing persamaan regresi digunakan perbedaan waktu (timelag) 1 (satu) bulan dengan prediktan. 


\section{c) Root Mean Square Error}

Metode ini digunakan untuk mengetahui besarnya penyimpangan yang terjadi antara nilai prediksi total hujan dibandingkan dengan nilai total hujan aktualnya yang terjadi selama satu tahun. Dari nilai ini dapat dilakukan analisa prediksi total hujan dengan prediktor mana diantara suhu maupun kelembapan udara atau suhu dan kelembapan udara yang memiliki nilai penyimpangan yang besar atau kecil (Wilks, 1995). Perlu diketahui bahwa untuk validasi hasil prakiraan semakin besar nilai RMSE, maka semakin jauh nilai data total hujan bulanan prakiraan terhadap total hujan aktualnya dan semakin kecil nilai RMSE maka semakin baik prediksi total hujannya. Karena tingkat kesalahan yang dapat diminimalisir dapat meningkatkan tingkat akurasi prakiraan (Soetamto dan Maria, 2010).

\section{d) Koefisien Korelasi}

Nilai koefisien korelasi Pearson (Trihendradi, 2005) di gunakan untuk menentukan besarnya hubungan atau kedekatan antara total hujan yang telah diprediksi dengan total hujan aktual yang terjadi. Dalam hal ini kedekatan yang dicari adalah besarnya nilai prediksi dengan menggunakan prediktor mana diantara suhu atau kelembapan udara atau suhu dan kelembapan udara yang paling baik. Kuat tidaknya hubungan (Prihatini dkk, 2000) antara prediksi total hujan bulanan dengan total hujan observasinya dapat diukur dengan suatu nilai yang disebut dengan koefisien korelasi. Nilai koefisien korelasi ini paling sedikit -1 dan paling besar 1. Jadi $r=$ koefisien korelasi, dapat di nyatakan sebagai berikut:

a) Jika harga $r$ mendekati +1 , berarti hubungan antara total hujan bulanan

b) yang diprediksi dengan total hujan bulanan observasinya sangat kuat dan positif.

c) Jika harga $r$ mendekati -1, berarti hubungan antara total hujan bulanan yang diprediksi dengan total hujan bulanan observasinya sangat kuat dan negatif.

d) Jika harga $r$ mendekati +0.5 atau -0.5 , berarti hubungan antara total hujan bulanan yang diprediksi dengan total hujan bulanan observasinya dianggap cukup kuat.

e) Jika harga $r$ lebih kecil dari +0.5 atau lebih besar dari -0.5, berarti hubungan antara total hujan bulanan yang diprediksi dengan total hujan bulanan observasinya dianggap lemah.

Untuk Validasi hasil prakiraan dengan menggunakan koefisien korelasi, semakin kuat korelasi maka semakin baik hasil validasi berarti semakin tinggi tingkat akurasi prakiraan.

\section{HASIL DAN PEMBAHASAN}

\section{A. Hasil}

Bentuk persamaan regresi linier sederhana hasil pengolahan menggunakan data suhu (T) dan data kelembapan udara (RH) disajikan pada tabel 1. Prediksi curah hujan tahun 2011 menggunakan variabel penduga suhu udara dan kelembapan udara dapat dilihat pada tabel 2. Bentuk persamaan regresi linier berganda hasil pengolahan menggunakan data suhu udara, kelembapan udara dan total hujan bulanan dicantumkan pada tabel 3.

Tabel 1. Persamaan regresi linier sederhana untuk prediksi total hujan bulanan dengan prediktor $\mathrm{T}$ dan RH (Sumber: Pengolahan Data).

\begin{tabular}{clcc}
\hline No & \multicolumn{1}{c}{ Bulan } & $\begin{array}{c}\text { Persamaan Regresi Linier Sederhana } \\
\text { Menggunakan Prediktor } \\
\text { Suhu Udara (T) }\end{array}$ & $\begin{array}{c}\text { Menggunakan Prediktor } \\
\text { Kelembaban Udara (RH) }\end{array}$ \\
\hline 1 & JANUARI & $\mathrm{Y}=2889.6-99.5 \mathrm{X}$ & $\mathrm{Y}=-1022.6+15.4 \mathrm{X}$ \\
2 & FEBRUARI & $\mathrm{Y}=1496.3-49.5 \mathrm{X}$ & $\mathrm{Y}=-1936.2+25 \mathrm{X}$ \\
3 & MARET & $\mathrm{Y}=1316.8-40.4 \mathrm{X}$ & $\mathrm{Y}=183.9+0.7 \mathrm{X}$ \\
4 & APRIL & $\mathrm{Y}=3610.3-125.5 \mathrm{X}$ & $\mathrm{Y}=-1231.9+17.5 \mathrm{X}$ \\
5 & MEI & $\mathrm{Y}=1850.9-60.5 \mathrm{X}$ & $\mathrm{Y}=-1160.9+16.3 \mathrm{X}$ \\
6 & JUNI & $\mathrm{Y}=1021.6-32.5 \mathrm{X}$ & $\mathrm{Y}=-555.7+8.5 \mathrm{X}$ \\
7 & JULI & $\mathrm{Y}=2066.4-71.2 \mathrm{X}$ & $\mathrm{Y}=-1170.1+16.3 \mathrm{X}$ \\
8 & AGUSTUS & $\mathrm{Y}=2381.2-83 \mathrm{X}$ & $\mathrm{Y}=-1378.5+19.3 \mathrm{X}$ \\
9 & SEPTEMBER & $\mathrm{Y}=2081.4-72.8 \mathrm{X}$ & $\mathrm{Y}=-795.8+11.4 \mathrm{X}$ \\
10 & OKTOBER & $\mathrm{Y}=2788.7-96.4 \mathrm{X}$ & $\mathrm{Y}=-994+14.5 \mathrm{X}$ \\
11 & NOPEMBER & $\mathrm{Y}=3691.3-130.2 \mathrm{X}$ & $\mathrm{Y}=-1421.7+19.7 \mathrm{X}$ \\
12 & DESEMBER & $\mathrm{Y}=178.1+5 \mathrm{X}$ & $\mathrm{Y}=-1071.8+15.9 \mathrm{X}$ \\
\hline
\end{tabular}


Tabel 2. Prediksi total hujan bulanan tahun 2011 menggunakan prediktor T dan RH di Stasiun Meteorologi Depati Amir Pangkalpinang (Sumber: Pengolahan Data).

\begin{tabular}{clcc}
\hline No & Bulan & $\begin{array}{c}\text { Prediksi CHT } \\
\text { Tahun 2011 (mm) }\end{array}$ & $\begin{array}{c}\text { Prediksi CHRH } \\
\text { Tahun 2011 (mm) }\end{array}$ \\
\hline 1 & Januari & 301.7 & 300.8 \\
2 & Februari & 206.7 & 155.1 \\
3 & Maret & 256.1 & 245.5 \\
4 & April & 331.9 & 253.4 \\
5 & Mei & 244.1 & 229.4 \\
6 & Juni & 136.0 & 154.8 \\
7 & Juli & 123.0 & 145.8 \\
8 & Agustus & 125.3 & 121.2 \\
9 & September & 62.4 & 51.1 \\
10 & Oktober & 83.9 & 62.8 \\
11 & Nopember & 164.1 & 164.8 \\
12 & Desember & 311.5 & 259.1 \\
\hline
\end{tabular}

Tabel 3. Persamaan regresi linier berganda menggunakan prediktor T dan RH (Sumber: Pengolahan Data).

\begin{tabular}{clc}
\hline No & Bulan & Persamaan Regresi Linire Berganda \\
\hline 1 & Januari & $\mathrm{Y}=689.7-51.1 \mathrm{X} 1+10.9 \mathrm{X} 2$ \\
2 & Februari & $\mathrm{Y}=73+10.9 \mathrm{X} 1-1.9 \mathrm{X} 2$ \\
3 & Maret & $\mathrm{Y}=80.7+4.5 \mathrm{X} 1+0.6 \mathrm{X} 2$ \\
4 & April & $\mathrm{Y}=93.5+0.8 \mathrm{X} 1+1.6 \mathrm{X} 2$ \\
5 & Mei & $\mathrm{Y}=54.7+4 \mathrm{X} 1+0.3 \mathrm{X} 2$ \\
6 & Juni & $\mathrm{Y}=-21.6+6.4 \mathrm{X} 1-0.2 \mathrm{X} 2$ \\
7 & Juli & $\mathrm{Y}=-77.6+8.5 \mathrm{X} 1-0.2 \mathrm{X} 2$ \\
8 & Agustus & $\mathrm{Y}=-58.3+6.9 \mathrm{X} 1-0.2 \mathrm{X} 2$ \\
9 & September & $\mathrm{Y}=-49+5.5 \mathrm{X} 1-0.2 \mathrm{X} 2$ \\
10 & Oktober & $\mathrm{Y}=-48.7+9.8 \mathrm{X} 1-0.6 \mathrm{X} 2$ \\
11 & Nopember & $\mathrm{Y}=-18.7+19.9 \mathrm{X} 1-3.3 \mathrm{X} 2$ \\
12 & Desember & $\mathrm{Y}=508.5-6.9 \mathrm{X} 1-0.2 \mathrm{X} 2$ \\
\hline
\end{tabular}

Perlu diketahui bahwa jika total hujan hasil observasi mengalami kenaikan dan total hujan hasil prediksi juga mengalami kenaikan atau sebaliknya, maka dapat dikatakan bahwa prediksi tersebut mendekati total hujan yang sebenarnya dan hasil prediksi tersebut adalah cukup baik.

Hasil perhitungan menunjukan bahwa pada tahun 2011 di dapat nilai koefisien korelasi Pearson antara simulasi prediksi total hujan bulanan menggunakan prediktor suhu udara adalah $r=0,63$; menggunakan prediktor kelembapan udara diperoleh sebesar $r=0,44$; menggunakan prediktor suhu udara dan kelembapan udara sekaligus diperoleh sebesar $\mathrm{r}=$ 0,63 .

\section{B. Pembahasan}

\section{a) Bulan Januari.}

Pada bulan Januari 2011 diperoleh nilai prediksi total hujan bulanan sebesar $301.7 \mathrm{~mm}$ menggunakan prediktor suhu udara. Penyimpangan terhadap total hujan observasi sebesar $46.8 \mathrm{~mm}$. Sementara itu menggunakan prediktor kelembapan udara didapat nilai total hujan bulanan prediksi sebesar $300.8 \mathrm{~mm}$. Penyimpangan terhadap data observasi diperoleh $47.7 \mathrm{~mm}$. Selanjutnya menggunakan prediktor suhu udara dan kelembapan udara diperoleh nilai prediksi total hujan bulanan sebesar $298.6 \mathrm{~mm}$. 
Penyimpangan terhadap total hujan aktualnya adalah $45.5 \mathrm{~mm}$.

\section{b) Bulan Februari}

Pada bulan Februari 2011 diperoleh nilai prediksi total hujan bulanan dengan menggunakan prediktor suhu udara sebesar $206.7 \mathrm{~mm}$. Penyimpangan terhadap data total hujan aktualnya sebesar $103.2 \mathrm{~mm}$. Menggunakan prediktor kelembapan udara diperoleh nilai prediksi total hujan bulanan sebesar $155.1 \mathrm{~mm}$.
Penyimpangan terhadap data observasi didapat $154.8 \mathrm{~mm}$. Sedangkan menggunakan prediktor suhu udara dan kelembapan udara diperoleh nilai prediksi total hujan sebesar 202.0 $\mathrm{mm}$. Penyimpangan terhadap data aktualnya sebesar $45.5 \mathrm{~mm}$.

Grafik perbandingan antara total hujan bulanan menggunakan prediktor $\mathrm{T}$ dengan data aktualnya tahun 2011 dapat dilihat pada gambar 1 , sedangkan prediksi menggunakan prediktor RH dapat dilihat pada gambar 2 .

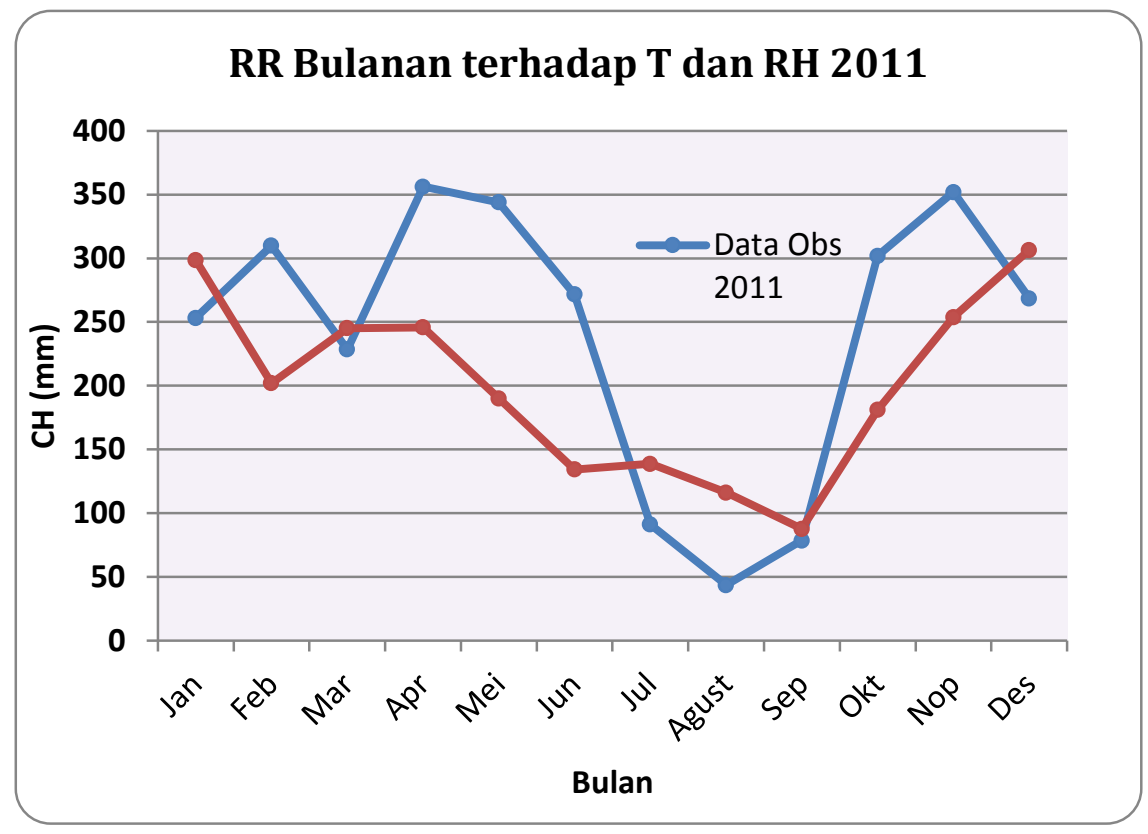

Gambar 1. Perbandingan antara prediksi total hujan bulanan dengan prediktor T terhadap data aktualnya di stasiun meteorologi Depati Amir Pangkalpinang tahun 2011 (Sumber: Pengolahan Data)

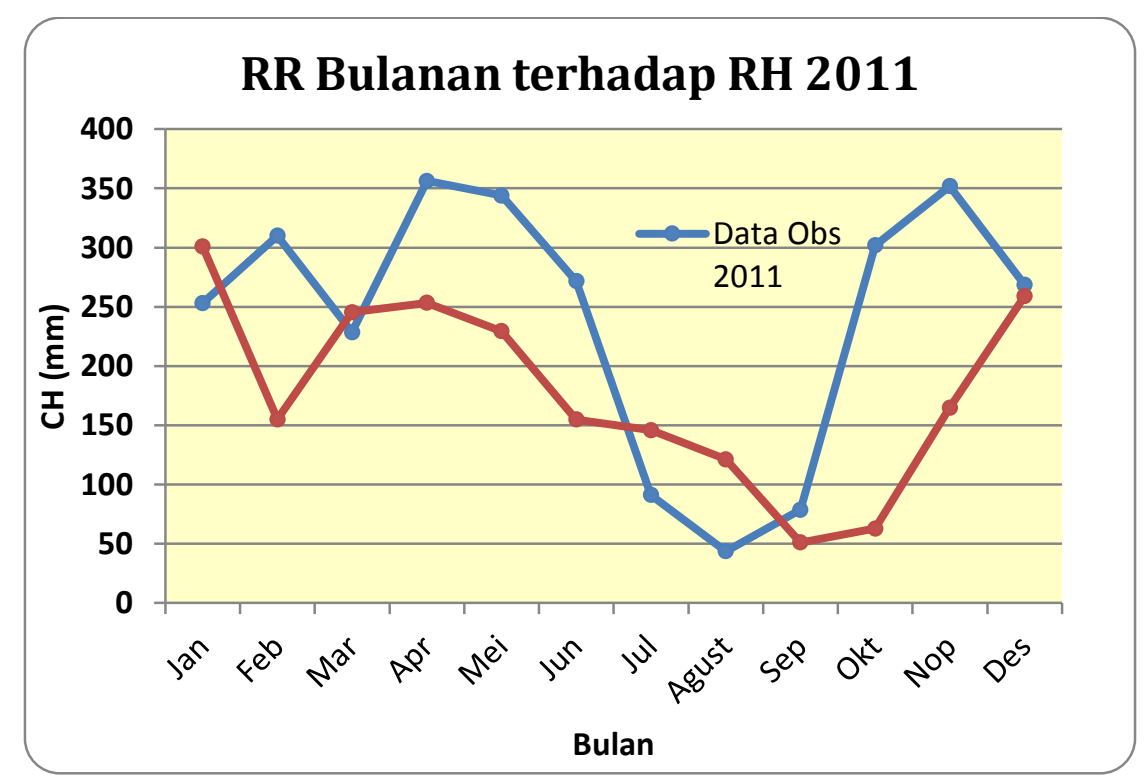

Gambar 2. Perbandingan antara prediksi total hujan bulanan dengan prediktor RH dengan hasil observasinya di stasiun meteorologi Depati Amir Pangkalpinang tahun 2011 (Sumber: Pengolahan Data) 


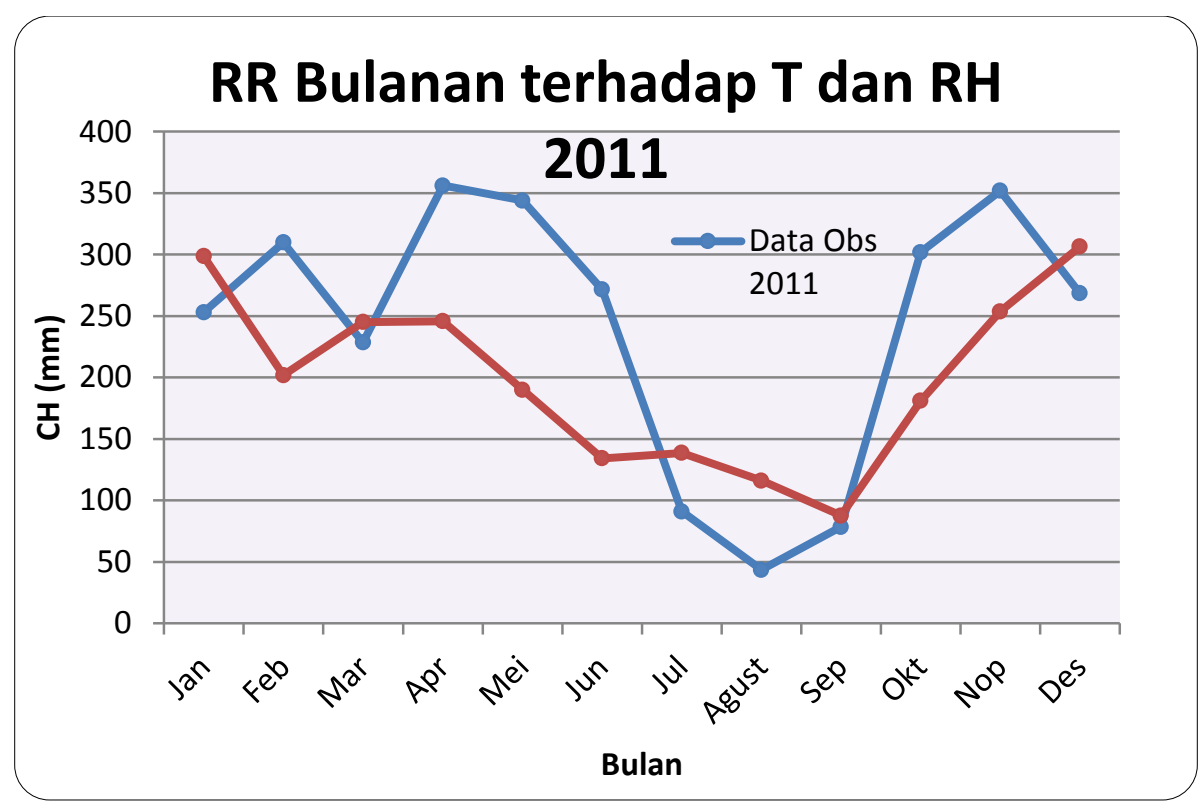

Gambar 3. Perbandingan antara prediksi total hujan bulanan menggunakan prediktor (T dan RH) dengan Total hujan bulanan observasi observasi di stasiun meteorologi Depati Amir Pangkalpinang 2011 (Sumber: Pengolahan Data)

\section{c) Bulan Maret}

Pada bulan Maret 2011 menggunakan prediktor suhu udara diperoleh nilai prediksi total hujan bulanan sebesar $256.1 \mathrm{~mm}$. Penyimpangan terhadap data total hujan aktualnya sebesar $27.6 \mathrm{~mm}$. Menggunakan prediktor kelembapan udara diperoleh nilai prediksi total hujan bulanan sebesar $245.5 \mathrm{~mm}$. Penyimpangan terhadap data observasi didapat $17.0 \mathrm{~mm}$. Sedangkan menggunakan prediktor suhu udara dan kelembapan udara diperoleh nilai prediksi total hujan sebesar $245.1 \mathrm{~mm}$. Penyimpangan terhadap data aktualnya sebesar $16.6 \mathrm{~mm}$.

\section{d) Bulan April}

Pada bulan April 2011 dengan menggunakan prediktor suhu udara diperoleh nilai prediksi total hujan bulanan sebesar 331.9 mm. Penyimpangan terhadap data total hujan aktualnya sebesar $24.3 \mathrm{~mm}$. Menggunakan prediktor kelembapan udara didapat nilai prediksi total hujan bulanan sebesar $253.4 \mathrm{~mm}$. Penyimpangan terhadap data observasi sebesar $102.8 \mathrm{~mm}$. Sedangkan menggunakan prediktor suhu udara dan kelembapan udara didapat nilai prediksi total hujan bulanan sebesar $245.9 \mathrm{~mm}$. Penyimpangan terhadap data aktualnya sebesar $110.3 \mathrm{~mm}$.

\section{e) Bulan Mei}

Pada bulan Mei 2011 dengan menggunakan prediktor suhu udara diperoleh nilai prediksi total hujan bulanan sebesar 244.1 mm. Penyimpangan terhadap data aktualnya sebesar $99.8 \mathrm{~mm}$. Sementara itu menggunakan prediktor kelembapan udara diperoleh nilai prediksi total hujan bulanan sebesar $229.4 \mathrm{~mm}$. Penyimpangan terhadap data observasi sebesar $114.5 \mathrm{~mm}$. Sedangkan menggunakan prediktor suhu udara dan kelembapan udara didapat nilai diprediksi total hujan bulanan sebesar $190.0 \mathrm{~mm}$. Penyimpangan terhadap data aktualnya sebesar $153.9 \mathrm{~mm}$.

\section{f) Bulan Juni}

Pada bulan Juni 2011 dengan menggunakan prediktor suhu udara diperoleh nilai prediksi total hujan bulanan sebesar 136.0 mm. Penyimpangan terhadap data aktualnya sebesar $135.6 \mathrm{~mm}$. Menggunakan predictor kelembapan udara didapat nilai prediksi total hujan bulanan sebesar $154.8 \mathrm{~mm}$. Penyimpangan terhadap data observasi sebesar $116.8 \mathrm{~mm}$. Sedangkan menggunakan prediktor suhu udara dan kelembapan udara didapat nilai prediksi total hujan bulanan sebesar $134.4 \mathrm{~mm}$. Penyimpangan terhadap data observasi sebesar $137.2 \mathrm{~mm}$.

\section{g) Bulan Juli}

Pada bulan Juli 2011 dengan menggunakan prediktor suhu udara diperoleh nilai prediksi total hujan bulanan sebesar 123.0 mm. Penyimpangan terhadap data total hujan aktualnya sebesar $31.9 \mathrm{~mm}$. Menggunakan prediktor kelembapan udara didapat nilai prediksi total hujan bulanan sebesar $145.8 \mathrm{~mm}$. Penyimpangan terhadap data observasi sebesar $54.7 \mathrm{~mm}$. Sedangkan menggunakan prediktor suhu udara dan kelembapan udara didapat nilai 
prediksi total hujan bulanan sebesar $138.6 \mathrm{~mm}$. Penyimpangan terhadap data aktualnya sebesar $47.5 \mathrm{~mm}$.

\section{h) Bulan Agustus}

Pada bulan Agustus 2011 dengan menggunakan prediktor suhu udara diperoleh nilai prediksi total hujan bulanan sebesar 125.3 $\mathrm{mm}$. Penyimpangan terhadap data total hujan aktualnya sebesar $81.7 \mathrm{~mm}$. Menggunakan prediktor kelembapan udara didapat nilai prediksi total hujan bulanan sebesar $121.2 \mathrm{~mm}$. Penyimpangan terhadap data actual sebesar 77.6 $\mathrm{mm}$. Sedangkan menggunakan predictor suhu udara dan kelembapan udara didapat nilai prediksi total hujan bulanan sebesar $116.2 \mathrm{~mm}$. Penyimpangan terhadap data observasi sebesar $72.6 \mathrm{~mm}$.

\section{i) Bulan September}

Pada bulan September 2011 dengan menggunakan prediktor suhu udara diperoleh nilai prediksi total hujan bulanan sebesar 62.4 $\mathrm{mm}$. Penyimpangan terhadap data total hujan aktualnya sebesar $116.2 \mathrm{~mm}$. Menggunakan prediktor kelembapan udara diperoleh nilai prediksi total hujan bulanan sebesar $51.1 \mathrm{~mm}$. Penyimpangan terhadap data observasi didapat $27.5 \mathrm{~mm}$. Sedangkan menggunakan prediktor suhu udara dan kelembapan udara diperoleh nilai prediksi total hujan sebesar $87.7 \mathrm{~mm}$. Penyimpangan terhadap data aktualnya sebesar $9.1 \mathrm{~mm}$.

\section{j) Bulan Oktober}

Pada bulan Oktober 2011 dengan menggunakan prediktor suhu udara diperoleh nilai prediksi total hujan bulanan sebesar 83.9 $\mathrm{mm}$. Penyimpangan terhadap data actual total hujan bulanan sebesar $218.0 \mathrm{~mm}$. Menggunakan prediktor kelembapan udara didapat nilai prediksi total hujan bulanan sebesar $62.8 \mathrm{~mm}$. Penyimpangan terhadap data aktualnya sebesar $239.1 \mathrm{~mm}$. Sedangkan menggunakan prediktor suhu udara dan kelembapan udara diperoleh nilai prediksi total hujan bulanan sebesar 181.1 $\mathrm{mm}$. Penyimpangan terhadap data aktualnya sebesar $120.8 \mathrm{~mm}$.

\section{k) Bulan Nopember}

Pada bulan Nopember 2011 dengan menggunakan prediktor suhu udara diperoleh nilai prediksi total hujan bulanan sebesar 164.1 $\mathrm{mm}$. Penyimpangan terhadap data total hujan aktualnya sebesar $187.8 \mathrm{~mm}$. Menggunakan prediktor kelembapan udara diperoleh nilai prediksi total hujan bulanan sebesar $164.8 \mathrm{~mm}$. Besar penyimpangan terhadap data actual sebesar $187.1 \mathrm{~mm}$. Sedangkan menggunakan prediktor suhu udara dan kelembapan udara didapat nilai prediksi total hujan bulanan sebesar $253.7 \mathrm{~mm}$. Penyimpangan terhadap data observasi sebesar $98.2 \mathrm{~mm}$.

\section{1) Bulan Desember}

Pada bulan Desember 2011 dengan menggunakan prediktor suhu udara diperoleh nilai prediksi total hujan bulanan sebesar 311.5 $\mathrm{mm}$. Penyimpangan terhadap data actual total hujan bulanan sebesar $43.0 \mathrm{~mm}$. Menggunakan prediktor kelembapan udara dihasilkan nilai prediksi total hujan bulanan sebesar $259.1 \mathrm{~mm}$. Besar penyimpangan terhadap data actual sebesar $9.4 \mathrm{~mm}$. Sedangkan menggunakan prediktor suhu udara dan kelembapan udara diperoleh nilai prediksi total hujan bulanan sebesar $306.5 \mathrm{~mm}$. Penyimpangan terhadap data observasi sebesar $38.0 \mathrm{~mm}$.

Dengan menggunakan nilai RMSE rerata terlihat bahwa secara keseluruhan bahwa prediksi total hujan bulanan 2011 di daerah studi menghasilkan nilai RMSE rerata sebesar $14.8 \mathrm{~mm}$ dengan menggunakan prediktor suhu udara. RMSE rerata sebesar $14.5 \mathrm{~mm}$ menggunakan predictor kelembapan udara. Sedangkan untuk prediksi total hujan bulanan dengan menggunakan prediktor suhu udara dan kelembapan udara diperoleh nilai rerata RMSE sebesar $14.9 \mathrm{~mm}$. Dari ketiga prediktor ini nampak bahwa prediksi total hujan bulanan dengan menggunakan prediktor suhu dan kelembapan udara memiliki nilai penyimpangan yang relatif lebih besar daripada menggunakan prediktor suhu atau kelembapan udara. Nilai penyimpangan luaran prediksi menunjukkan nilai penyimpangan yang cukup besar. Sedangkan untuk prediksi total hujan bulanan menggunakan prediktor kelembapan udara mempunyai nilai penyimpangan yang relatif lebih rendah dari yang lainnya. Hal tersebut di atas menunjukkan bahwa prediksi total hujan bulanan 2011 dengan menggunakan prediktor suhu dan kelembapan udara cukup baik dibandingkan dengan prakiraan menggunakan prediktor suhu maupun kelembapan udara. Meskipun nilai RMSE terhitung lebih besar yaitu $0.1 \mathrm{~mm}$ dari suhu udara dan $0.4 \mathrm{~mm}$ dari kelembapan, namun nilai korelasinya merupakan tertinggi di antara ketiga model regresi.

Grafik prediksi total hujan bulanan menggunakan prediktor suhu udara dengan grafik total hujan hasil observasi secara umum nampak pola yang terjadi adalah cenderung teratur, dan terlihat prediksi total hujan cenderung mengikuti total hujan aktualnya. Namun, ada selisih curah hujan hasil prediksi dengan data observasi tidak konsisten. Pada 
model regresi dengan predictor suhu udara atau kelembapan, hasil prediksi hujan lebih rendah dari data observasi terjadi pada bulan Februari, April, Mei, Juni, September, Oktober dan November. Sedangkan dengan menggunakan predictor suhu dan kelembapan udara secara bersamaan, hasil prediksi bulan September mempunyai nilai lebih tinggi disbanding data observasi. Pada bulan Februari, hasil prediksi dari ketiga model regresi menunjukkan kesamaan dimana cuah hujan meningkat setelah Januari, padahal pada data observasi curah hujan bulan Februari mengalami penurunan.

\section{PENUTUP}

Berdasarkan uraian yang telah dipaparkan oleh penulis dalam bab-bab tersebut di atas, maka dapat ditarik beberapa kesimpulan sebagai berikut:

1. Prediksi total hujan bulanan tahun 2011 di stasiun meteorologi Depati Amir Pangkalpinang dengan menggunakan prediktor suhu udara (T) dan menggunakan suhu udara dengan kelembapan udara ( $\mathrm{T}$ dan RH) menunjukkan nilai prediksi yang cukup baik pada bulan September, sedangkan menggunakan kelembapan udara (RH) nilai prediksi cukup baik tampak pada bulan Desember.

2. Prediksi total hujan bulanan menggunakan dua prediktor suhu udara dan kelembapan udara sekaligus ( $\mathrm{T}$ dan $\mathrm{RH}$ ) menggunakan persamaan regresi linier berganda menghasilkan luaran yang relatif lebih baik dibandingkan dengan menggunakan satu prediktor.

\section{DAFTAR PUSTAKA}

[1] Sandy, I.M. (1995). Atlas Republik Indonesia. Depok: PT Indograf Bakti \& Jurusan Geografi FMIPA-UI.

[2] Wirjohamidjojo, S. \& Swarinoto, Y.S (2010). Iklim Kawasan Indonesia. Jakarta: Badan Meteorologi Klimatologi dan Geofisika, Jakarta.

[3] Nieuwolt, S. (1977). Tropical Climatology: An introduction to the climates of low latitudes. Toronto: John Wiley \& Sons.

[4] Kartasapoetra, A.G. (2006). Klimatologi: Pengaruh iklim terhadap tanah dan tanaman. Jakarta: Bumi Aksara.
[5] Wirjohamidjojo, S. \& Y.S. Swarinoto. (2007). Praktek Meteorologi Pertanian. Jakarta: Badan Meteorologi dan Geofisika.

[6] Tjasyono, B. (1999). Klimatologi Umum. Bandung: ITB.

[7] Soepangkat. (1994). Pengantar Meteorologi. Jakarta: Akademi Meteorologi dan Geofisika.

[8] Tanudidjaja, (1993). Ilmu Pengetahuan Bumi dan Antariksa. Jakarta : Penerbit Departemen Pendidikan dan Kebudayaan.

[9] Wirjohamidjojo, S. (2006). Kamus Istilah Meteorologi Aeronautika. Jakarta : Penerbit Badan Meteorologi dan Geofisika.

[10] Nazir, M. (2003). Metode Penelitian. Jakarta: PT Ghalia Indonesia.

[11] Usman, H. \& Akbar, R.P.S. (2000). Pengantar Statistik. Jakarta: Penerbit Bumi Aksara.

[12] Sudjana. (1995). Metoda Statistika. Bandung: Penerbit Tarsito.

[13] Wilks, D.S. (1995). Statistical Methods in the Atmospheric Science, San Diego: Academic Press.

[14] Soetamto \& Maria, U.A. (2010). Modul Pelatihan Peningkatan Akurasi Prakiraan Musim. Jakarta: BMKG.

[15] Trihendradi, C. (2005). Step By Step SPSS 13, Analisis Data Statistik. Yogyakarta: Penerbit ANDI.

[16] Prihatini, Djatmiko, H.T., \& Swarinoto, Y.S. (2000). Kaitan Southern Oscillation Index Dengan Total Hujan Bulanan di Pontianak. Jurnal Meterologi \& Geologi, 1(1). 